Wood, Margaret ORCID:

https://orcid.org/0000-0001-5067-1978, Pennington, Andrew and Su, Feng (2018) Pre-figurative practice and the educational leadership of Sir Alec Clegg in the West Riding of Yorkshire, England (1945-1974). Journal of Educational Administration and History, 50 (4). pp. 299-315.

Downloaded from: http://ray.yorksj.ac.uk/id/eprint/3386/

The version presented here may differ from the published version or version of record. If you intend to cite from the work you are advised to consult the publisher's version: https://www.tandfonline.com/doi/full/10.1080/00220620.2018.1501010

Research at York St John (RaY) is an institutional repository. It supports the principles of open access by making the research outputs of the University available in digital form. Copyright of the items stored in RaY reside with the authors and/or other copyright owners. Users may access full text items free of charge, and may download a copy for private study or non-commercial research. For further reuse terms, see licence terms governing individual outputs. Institutional Repository Policy Statement

\title{
RaY
}

Research at the University of York St John

For more information please contact RaY at ray@yorks.ac.uk 


\title{
Pre-figurative practice and the educational leadership of Sir Alec Clegg in the West Riding of Yorkshire, England (1945-1974)
}

\author{
Margaret Wood ${ }^{\mathrm{a}}$, Andrew Pennington ${ }^{\mathrm{b}}$ and Feng Su ${ }^{\mathrm{c}}$ \\ ${ }^{a b}$ School of Education, York St John University, York, UK; ${ }^{c}$ Faculty of Education, Liverpool \\ Hope University, Liverpool, UK.
}

Corresponding author

Margaret Wood, School of Education, York St John University, Lord Mayor's Walk, York, YO31 7EX, UK. Email: m.wood@yorksj.ac.uk

Co-authors

Andrew Pennington, School of Education, York St John University, Lord Mayor's Walk, York, YO31 7EX, UK. Email: a.pennington@yorksj.ac.uk

Feng Su, Faculty of Education, Liverpool Hope University, Hope Park, Liverpool, L16 9JD, UK. Email: suf@hope.ac.uk

Margaret Wood is Senior Lecturer in the Faculty of Education and Theology at York St John University, UK. She has a particular research interest in educational enquiry in higher education, through which she aims to develop pedagogic understandings by creating structures and conditions for genuine dialogue to develop student agency and to embed this within practices. She is co-editor of Cosmopolitan Perspectives on Academic Leadership in Higher Education (2017), published by Bloomsbury.

Andrew Pennington was a senior officer in two local authority education and children's services departments. Following his retirement he was chair of governors at a large secondary comprehensive school and now chairs the Board of Trustees of a newly-formed multiacademy trust. He is currently conducting doctoral research on democratic governance and community accountability in multi-academy trusts. 
Feng Su is Senior Lecturer in Education at Liverpool Hope University, UK, and a Visiting Research Fellow to The Education University of Hong Kong. His main research interests and writings are located within the following areas: cross-cultural learning contexts and the development of the learner in higher education settings, and academic practice and professional learning. His most recent books include Cosmopolitan Perspectives on Academic Leadership in Higher Education (edited with Wood 2017); The Reorientation of Higher Education: Challenging the East-West Dichotomy (edited with Adamson and Nixon 2012); Professional Ethics: Education for a Humane Society (edited with McGettrick 2012); and Chinese learning journeys: Chasing the dream (2011). 


\section{Pre-figurative practice and the educational leadership of Sir Alec Clegg in the West Riding of Yorkshire, England (1945-1974)}

This article recalls a time when local government infrastructure was strong and a Chief Education Officer's (CEO) vision could be realised across a region, in Clegg's case the West Riding of Yorkshire, one of the largest of the pre-1974 counties in England. It is timely to revisit Clegg's educational leadership and practice from 19451974, as a valuable source of learning, and challenge to the current ideologicallyinformed policy rhetoric which has undermined the framework of democratic educational decision-making. The authors identify four possible areas to learn from Clegg's work. Firstly, the need for CEOs or their modern-day equivalents or successors, to consider their potential as political and community leaders; secondly, Clegg's leadership style prefigures some of the recent discussion about the leadership of public services in uncertain times; thirdly a re-evaluation of administration and bureaucracy; and lastly the need for supportive partnerships to enable schools to thrive.

Keywords: Alec Clegg; education leadership; education policy; local authority; schools;

\section{Introduction}

The educational leadership of Alexander Bradshaw Clegg, referred to in this article as Alec Clegg which is the more customary form of his name, or 'Sir Alec Clegg' (he was knighted in the Queen’s Birthday Honours, 12th June 1965), ‘a seminal figure of twentieth-century education' (Crawford 2008, 101) and an inspirational chief education officer (Benn 2012) is as significant now as it was during his tenure at the West Riding of Yorkshire during the period commencing after the second world war and extending into the 1970s. The West Riding Education Service had its headquarters in Wakefield and Clegg's time there is recorded by a Wakefield Civic Society blue plaque commemorating 'one of the foremost influences nationally on comprehensive education’. 
Such was his influence in the West Riding that 'To be a West Riding teacher, head or adviser was to know that you were part of a great enterprise and associated with something generally acknowledged as very special and at the forefront of educational practice.' (Brighouse 2008, 103). Clegg’s influence and stature as a ‘shaper’ of education policy and practice which extended across the broad swathe of educational provisions is recognised, and he is to be placed as pre-eminent among the few great chief education officers who:

$$
\begin{aligned}
& \text { influenced and created developments in music, the arts, and sport in and out of school } \\
& \text { and college, and their writ ran from nursery through infant, junior, secondary, sixth } \\
& \text { forms and the youth service to further education colleges, adult education, teacher } \\
& \text { education and higher education outside the old universities. Many education officers } \\
& \text { missed that opportunity but the few great ones laid the foundation of what we now } \\
& \text { recognise as outstanding provision. (Brighouse 2008, 103-104). }
\end{aligned}
$$

Clegg has been described as an administrator who was able to 'retain this humanity while exercising social power' and who spoke with a 'simple honesty' which avoided the use of jargon (Trimble 1971, 2-3). In outlining Clegg's qualities Newsam (2008:111-112) suggests that together these created 'a particular ethos in the West Riding' and enabled his ideas to be enacted in practice. Glimpses of the person are gleaned from Trimble, who describes his impressions of Clegg when he addressed the $20^{\text {th }}$ Annual Conference of the Ontario Association for Curriculum Development in 1971. There are some contrasts in Trimble’s description, for whilst Clegg had ‘warm eyes’ there was also a hint of exasperation too for he had 'seen a lot of folly in his day'. Similarly, whilst he was a 'gentle man', his feelings about matters on which he felt strongly also came to the fore. For example, on one occasion in the speech, his anger and exasperation could be seen when he spoke about the consequences of a focus on measurement and testing in schools (Trimble, 1971). Two longserving former teachers who worked during the period of the West Riding administration at the first purpose-built comprehensive school in the West Riding of Yorkshire which opened 
in 1956, shared some reflections on the lasting impact of the foundations and ethos of the years of the Clegg administration. Although they had no personal contact with Clegg, they offered some insights into aspects of the 'particular ethos' of the West Riding to which Newsam (2008) referred, through their experiences in this school. They captured this in words such as ‘dynamism’ and 'pioneering'. As one of these respondents said:

the people who were on the staff in those very early years really did have that sense of being pioneers, they talk about tremendous awareness of being part of something very special.

The other respondent had a similar sense of the dynamism and the attention the school gained from visitors wishing to see and learn from practice there:

it was this dynamism, that's a word isn’t it, dynamism ... and I know it had visits from people all over the world in its formative years because it was this pioneering, purposebuilt comprehensive and people came to see how it worked.

Something of the legacy of the Clegg era endures in the school even though huge changes and policy shifts have occurred in education since that time. Whilst they were aware of the need to avoid looking back at the Clegg era through rose-tinted spectacles and to 'guard against too much thinking that, you know, this was a golden age when everything was wonderful' as one of them said, nevertheless they identified a special mix of factors which existed and combined to form something lasting:

I don't think you've totally destroyed that foundation that was laid in the 70's and that belief in what children are capable of. Particularly in terms of creative work. I don't think they have killed that off. They might have watered it down and they might have sort of brought back the kind of emphasis on testing and results that Alec Clegg used to criticise so much, but I am not sure that they have totally taken that away. 
Much has been written about Clegg’s achievements in many aspects of his work, including but not limited to his championing of the arts in the curriculum, the priority he afforded to teacher training, the Middle schools, the role and work of Local Education Authority (LEA) inspectors and advisers, and his commitment to comprehensive education. The main concern of this article is the relevance of Clegg's work for our own times. Much of the world of local authorities and educational administration from Clegg's time may be fairly unrecognisable today in an era where local democratic structures of governance have been eroded. This article recalls a time when local government infrastructure was strong and enabled the vision of the Chief Education Officer (CEO) to be realised across one of the largest of the pre-1974 counties in England. This would be impossible today. Government education policy reforms over the years since then have put paid to this:

under the influence of a New Right coalition, successive Conservative governments introduced a series of educational reforms which have reversed the advance of democratic educational progress by returning to the pre-democratic educational traditions and structures of the past. (Carr and Hartnett 1996, 199).

It is therefore timely to revisit this era, not primarily out of historical curiosity but as a valuable source of learning and challenging the ideologically-informed policy rhetoric which has undermined the framework of democratic educational decision-making, for:

it is by seeking ways to create more democratic educational decision-making processes that their legitimacy can be challenged and more democratically informed educational policies can be advanced. (Carr and Hartnett 1996, 198)

The 'prefigurative practice' referred to in the title of this article references the idea of extracting 'the prospect of hope from what has been achieved to date, and the opportunity for new knowledge and understandings’' (Fielding and Moss 2011, 149). There are many ways in which Clegg's thought and practice anticipated future trends and laid foundations for a better prospect. Clegg's contribution to promoting equitable educational provision, his belief in the 
pernicious effects of examination pressure and selection by academic ability, his concern for social justice to ensure opportunities for disadvantaged children, are all examples which provide inspiration and some 'prospect of hope' at a time when the legacy of twentieth century Tory government policy lives on and education policy is driven by 'Right-wing ideological beliefs in education as a mechanism for the development of an hierarchical society’ (Tomlinson 2005, 220). Clegg’s advocacy of measures such as social education centres and family support centred on high schools, prefigured what we now know as Children's Centres and extended schools. He understood the value of schools being placed at the heart of their communities. For example, in his Presidential address to the North of England Conference he spoke of the best secondary schools as 'centres of the community which they serve’. (Clegg, 3rd January 1972b).

His idea that 'education will have to be like an overcoat - something which one can take on and off as the circumstances of life demand' (Clegg, 21st April 1972c, Institute of Public Relations Conference), prefigured the importance afforded to lifelong learning. He saw the need for stronger connections between services dealing with children at risk and in trouble, particularly education and social services; he advocated early learning and recognised the importance of support for parents as for example when he spoke about preschool playgroups as a form of further education for mothers who helped/volunteered with the possibility of this being linked to some form of certification or qualification (Barnsley and District Liaison Committee conference, 25th November 1973). It is apparent how ideas such as these anticipated future ideas and practices.

The data drawn on was gathered through research from documents in the special collections held by Leeds University Library, the National Arts Education Archive at the Yorkshire Sculpture Park and the West Yorkshire Archive in Wakefield. The writing also 
draws from sources of wider published literature including books, journal articles and newspapers. The archival records from which to draw are immense and we duly acknowledge that only a fraction of the available materials has been used in the writing of this article. Data from a semi-structured interview with two retired teachers who spent their entire teaching careers at the first purpose-built comprehensive school in the West Riding of Yorkshire are drawn on to illuminate something of how the West Riding ethos was experienced in the Clegg years and beyond through what endures. Ethical protocols were followed in gathering this data and necessary permissions gained from the respondents and University Research Ethics Committee approval was granted.

\section{Historical background}

The backdrop, when Clegg assumed the role of CEO in 1945, was post-war Britain, an era of optimism in which it was anticipated that people's war time sacrifices and the defeat of fascism would be rewarded with increased access to education, universal health and welfare provision leading to a more equal society. As the economic and political realities of the cold war and austerity began to take hold, this optimism was superseded by disillusionment as 'Education persisted as a means by which inequalities were created, legitimised and justified, and privileged groups continued to use the divisions and distinctions of schooling to confirm and reproduce their own position.' (Tomlinson 2005, 13-14).

He was appointed in 1945 as Deputy Education Officer of the West Riding of Yorkshire County Council and less than a year later, aged 35, Clegg took on the role of its Chief Education Officer (CEO). A background in local authority work and latterly in Worcestershire as its Deputy Education Officer, provided a foundation for the remit Clegg took on in the West Riding in his mid-30s although, as he later recalled: 
When I was appointed as Deputy Education Officer and, within months, as Chief Education Officer of the West Riding, one of the largest Authorities in the country, I had to forget the gentler qualities of Worcestershire and face the tougher facts of the coalfields and wool valleys of Yorkshire. (Clegg 1980, 139).

Clegg was CEO of the West Riding between 1945 and its dissolution in the 1974 local government reorganisation. This was a region of 'great contrasts', between the more densely populated industrial regions in the Yorkshire coalfield to the south-west, the rich agricultural and less densely populated areas of level topography and the Pennine upland (Hobson 2013, 2-3).

It spanned a very large area, being the third largest education authority in Britain (Times 1986, 18) and at the 1951 census, a population of just over one and a half million. In terms of the size and remit of the education service, there were 1300 schools and 300,000 pupils in them and over 110,000 students in Further Education institutions:

The service included optional nursery schools for children under five years of age, compulsory education for children of 5 to 16, optional schooling for youngsters beyond that age, and Technical and Teachers' Colleges for older students. We were responsible for all the education in the area, except that provided by the Universities and by the independent schools, which cover perhaps 5 percent of our school population. Our budget last year was £116 million. (Clegg, 1974d Sir John Adams lecture).

As previously indicated, it had a diverse economic, social, political and geographical landscape. This must have been a challenging remit to assume in terms of scale and complexity. Not only was it a large area but, as George noted, one with 'a heterogenous population contained in distinctive historical, geographical, social and ideological backgrounds within which context the schools' preoccupations, anxieties and terms of reference were set.' (2000, 154-155). 
There were undoubtedly many challenges in planning educational provision in a period of post-war reconstruction not only 'things as they were' in terms of the building stock, facilities and equipment but at this time in history also characterised by 'a deep wish for personal space, a great deal of hope and some optimism for things to come.' (George 2000, 156).

\section{Change for the better - Clegg's vision for the education system}

Clegg was a product of a relatively privileged background and an elite education. He was however driven by a strong sense of social justice and he saw the need to transform the lives of working class children through opening up access to educational opportunities. He believed passionately in the ability and potential of ordinary children from modest and poor backgrounds to achieve extraordinary things. Nowhere is this more evident than in his work fostering and encouraging art work and artistic expression amongst children and young people. He also believed very strongly that a child's intelligence was not fixed and could develop over time:

I cannot accept aptitude - aptitude cannot be detected (and this is supported by leading psychologists).

I don't accept three types of school because it means childhood is divisible into three types - this I don’t believe. (Clegg (n.d.), Alec Clegg Collection, National Arts Education Archive, AC/PL/26)

As such he was opposed to selection for secondary school at age 11 by means of the 11 plus test and incorporated the comprehensive ideal into the West Riding vision. Much of his career at the West Riding was dominated by the planning, consulting, negotiating, and political manoeuvring required to bring this vision into being according to the needs, circumstances and opportunities of different areas and communities in the West Riding. 
Clegg was opposed strongly to the new arrangements to be put in place upon the closure of the West Riding County Council in the 1974 reorganisation of local government. The Local Government Act 1972, which came into force in 1974, made sweeping changes to the organisation, operation and administration of local government in England and Wales. The changes were particularly significant for the West Riding of Yorkshire where the county council was abolished. It was replaced by new, smaller all-purpose metropolitan district councils created to cover the conurbations of west and south Yorkshire, centred on Leeds and Sheffield, whilst the predominantly rural north of the Riding was placed in a new and large county council of North Yorkshire. Clegg was deeply concerned about the detrimental effects of the re-organisation on education in disadvantaged communities and he feared that the proposed small districts were in danger of becoming the new educational priority areas (Gosden and Sharp 1978). Clegg was very aware of the connection between adverse social conditions and poor educational progress. He believed the local education authorities created in 1974, with dense concentration of adverse social and economic factors, would contribute to educational disadvantage. Aware of these impacts, and also perhaps the powerful influence of the West Riding County Council as a site of an alternative vision of education policy to that of national government, Clegg attributed the 1974 local government reorganisation to 'unpardonable ignorance or to political malevolence of a high order' (North of England Education Conference, Presidential Address, 3 January 1972b). He took a dim view of this:

The major point, as the Education Officer saw it, was that children born into culturally impoverished homes, with parents of a low level of aspiration, were among the most severely educationally handicapped of all children in the country. Many lived in 'the grey areas of industrial England which enjoy neither the attractions of the town nor the charm of the country'. Their need was above all for educational enrichment and this the West Riding had striven successfully to provide in the schools in such areas, but in future the schools would be administered by authorities which would be unable to offer 
any of the supporting services and resources which had in the past contributed to make them what they were. (Gosden and Sharp 1978, 43).

Ignoring the needs of children who were most in need of help would, he feared, create a rejected group in society and severe social problems as a consequence (Clegg, November 1971, speech 278A). He forecast a future in which increasingly machines would take over 'the only jobs which those amongst us with slower minds are capable of doing' and the implications - unemployability and people who ‘find themselves discarded'. This was 'a firstclass recipe for social unrest.' His foresight also enabled him to predict a time when the supply of university graduates would outstrip the demand for the kind of jobs 'believed to be appropriate for such students’. (Clegg, 21st April 1972c speech Institute of Public Relations Conference).

He came to understand the economic and social forces that restricted and oppressed a large proportion of the West Riding population and how access to education was a form of liberation that could transform lives. This concern and desire for change might have been rooted in social justice motives but he was also driven by a strong sense of how economic forces would shape the future. He saw that industrial and technological change would require a workforce with much higher skills beyond the simple technicians and clerks the post-World War II English school system seemed destined to produce. He understood that the future world of work would require creative individuals who could think logically, analyse, work collaboratively and flexibly and who had an understanding and commitment to lifelong learning. Part of his genius was in understanding that for the UK to succeed in the post-war world then the waste of talent and potential generated by the English school system was not simply unjust to individuals, families and communities but it was economically damaging too.

Clegg’s educational ideas and concern to tackle educational inequalities may be seen in many ways to epitomise some of the thinking of Tawney. Tawney $(1964,145)$ made a 
connection between educational opportunities and the life of a civilised society, 'As a society sows, so in the long run it reaps' seemed to capture the essence of what Clegg too realised in his drive to offer fair educational opportunities to those who may otherwise find themselves 'discarded', unemployable and marginalised. Tawney spoke out against the organisation of English education along social class lines and against the 'blight of social inferiority' (Tawney 1964, 142) and Clegg's commitment to addressing the unfairness and inequalities in the education system epitomises these values and is characteristic of how he discharged the role of professional public servant.

\section{Educational leadership}

Since the end of Alec Clegg's tenure and the demise of the West Ridding County Council, leadership thinking, theorising and practice in education has undergone an explosive growth, creating what Gronn (2003, 269) describes as 'a vast leadership industry out there of truly staggering proportions’. Thomson, Gunter, and Blackmore (2014, vii) set out how this industry promotes a 'one-best way to do leading and leadership, and to be a leader' characterising the coming together of policy prescriptions and off-the-peg activities and fixes for leaders as the 'Transnational Leadership Package (TLP)'. They conclude that this TLP, whilst bringing together a range of concepts and practices into a 'saleable form' to support government education policy, does not always meet the need of individual schools, students or their communities (x).

The phenomenal growth of this industry might be attributed to the way in which leadership has come to be seen by government and its agencies as fundamental to school autonomy which they deem the pre-requisite for successful schools. Taylor $(2009,5)$ lists what he concludes are the common characteristics of great schools, the first of which is a 'good leadership team'. The Department for Education (DfE) White Paper 'Educational 
Excellence Everywhere' (2016) sets out how leadership is seen as one of the elements of educational excellence. For example, paragraph 1.37 states: 'we want to put more power into the hands of the best school and system leaders, and to extend their reach. A more autonomous school system is even more dependent on outstanding educational leaders'. This discourse about leadership is fixated on the role of strong individual leaders who achieve great things through the power of their intellect and force of their personality. Policy on leadership and leadership development is thus driven by the notion of high profile, gifted and talented individuals rather than something distributed and exercised by individuals, groups and networks throughout a school (Middlewood, Abbot and Robinson, 2018, 14). Indeed, Taylor's book (2009) and ministerial speeches from the DfE are liberally peppered with names of individual headteachers, singled out for their successes and personal qualities. As Gronn (2003) puts it, the 'dominant contemporary conception of leadership remains the doctrine of "exceptionalism”,

It seems to us that this conception of 'exceptionalism' would not have sat well with Alec Clegg's view of leadership. Middlewood, Abbot and Robinson $(2018,20)$ suggest that leadership should be driven by the need to find ways of making things work in a school system of connected, interrelated and interacting individuals and institutions operating in an environment of increasing volatility, uncertainty, complexity and ambiguity. We would suggest that models of leadership which emerge from studying Clegg's work are more in tune with this imperative than the 'exceptionalism' on offer in government approved conceptions of contemporary school leadership. Alec Clegg exerted an influence far beyond the 'local'. His leadership was situated in the 'ordinariness' of everyday practices (see Su and Wood, 2017a) and we suggest that this represents a 'cosmopolitan outlook' which was informed by locally-situated knowledge drawn from the varied and specific cultural, political and social 
contexts of the West Riding. Su and Wood (2017b) argue that educational leadership needs such a cosmopolitan outlook to respond to the local and the wider worlds we inhabit.

The function of the Chief Education Officer was set out in the 1947 Act. Clegg developed the role to be that of an organisational, educational, political and community leader. The leadership task as he defined it required the generation and articulation of an educational vision for the West Riding and the negotiation and consensus building for it to be realised and sustained through the turbulent changes in politics (local and national) and education. The diverse nature of the West Riding meant different ideologies and interpretations of the purpose of schooling had to be reconciled and real support for a common purpose of education built up across the political spectrum. With hindsight, this might be considered a straightforward task at a time of national social democratic consensus which characterised the post-war era up until the late 1970s as compared with the more polarised political environment following the advent of neo-liberalism and the dominance of market ideology from the 1980s onwards. Nevertheless, the political and leadership skills required to navigate the political environment of the West Riding should not be underestimated. Labour and Tories had strongholds in different areas of the county and political control of the authority changed often. This required Clegg to be a consummate political operator who could articulate a vision and gain full support for it from both the Labour strongholds of the south Yorkshire coalfield and the Tory heartlands of rural north Yorkshire. He described some of what was required to adapt in the early days:

In 1945 I moved from the seemly and low key utterances of Worcestershire to the vitriolic eloquence and robust vernacular of the West Riding. A.L. Binns would sit through the worst and whisper to me: "Folk would pay pounds to listen to this.” But I was new and was alarmed. However, after I got over the original baptism I learnt to draw fun from it in a way which helped to keep us all going. (Times Educational Supplement, Sir Alec Clegg 4.10.1974b, 19) 
Clegg's reminiscence of his early days in the West Riding hint at some of the elements he was to forge into a highly effective leadership style: understanding the motivations and characters of individual actors in the system, reflection on events to identify learning, using humour to foster social interactions and building and sustaining good relationships with a diverse range of people. All of this enabled him to build alliances across political and ideological divides in pursuit of an agreed vision. This was painstaking, patient work which required both humility and a relentless focus on the vision. At its heart was being an attentive listener, an empathetic communicator as well as the ability to motivate and inspire both individuals and groups. Clegg’s leadership was also visible:

he did not sit in his high office waiting for inspiration to strike. Instead he appointed trusted advisors who sought constantly for those who were showing success, enlightenment and integrity in their work and then he went to see for himself what was afoot, and in what ways it could be aided and facilitated. He did not then say to everyone 'This is wonderful. You should follow suit' but contrived consultations and systems of in-service training which ensured a flow of information and possibilities of infection. (Address by J.M. Hogan, at the funeral of Sir Alec Clegg 1986).

There is no doubt he was inspirational and the strength of his character enabled him to have influence at the highest level. Ministers at the Department of Education and Science were left in no doubt where he stood. Edward Boyle (Tory Minister for Education 1962 1964) recalled him thus:

(he) carried weight simply by sheer force of being who he was, the person he was, and who made himself the spokesman of the ... less fortunate in our society. He didn’t just go on about the less fortunate, he became the accepted conscience of Curzon Street in this way. (Boyle 1971, 136).

Boyle also acknowledges Clegg's influence at the national level: 'we used to say, when something was proposed, “what would Alec Clegg think about this?’” (Boyle 1971, 136). Whilst political neutrality (in a party political sense) was a requirement of chief officers 
in local government, it is clear that Clegg understood and managed the politics of the Council, its members and the communities it served with confidence, clarity of moral purpose and integrity.

\section{Empowering teachers}

The philosophical foundation in which his plans for education were grounded is apparent in the text of his speeches and the archive of materials from his time in the West Riding. He was against the unquestioning adoption of practices by which the professional teacher becomes reduced to no more than a technician who follows instructions and who is thereby absolved from the responsibility of exercising professional judgement (Clegg 1966). He was convinced teachers must be given freedom for 'sound and wise experiment' and that it was profoundly important that education should have regard for emotional and spiritual development as well as for the intellect (Clegg 1946a). His philosophy resonates with some educators today and offers an alternative to the centralised, controlling and instrumental thrust of current government education policy. His words seem as relevant and vital now as they did in his time:

' the child's loves, hates, enthusiasms, hopes and fears, his imagination, his creative force, his initiative and a whole host of qualities which we can neither measure nor examine and which, because of this, we tend to grossly undervalue', mattered above the 'facts of the syllabus. (Clegg, 'What it means to me', n.d.-a AC/PL/12/2).

In his obituary in the Times $(1986,18)$ it was recorded that he was 'in and out of schools all the time, and his influence among teachers far beyond his own county was reinforced by his total conviction that they, the teachers, were the experts in what goes on in schools'. To free up space for teachers to focus on children it was important to 'cut down the paperwork to a minimum' and to this end Clegg involved a committee of teachers together with members of the Treasurer's staff and of Divisional Offices to 
go through all the forms that we use in the Department in an endeavour to abolish as many as they can and simplify the remainder. I hope to try and keep this anti-red-tape machinery in existence and to use it frequently. (Clegg 1946b)

He believed in the value of a physical environment conducive to learning, both for teacher professional learning and for children's learning. Woolley Hall, a residential inservice training centre planned and established in 1952, was set in beautiful surroundings and with attention paid to furnishing and colour schemes with regard for consideration of efficiency and comfort (Times Educational Supplement, Sir Alec Clegg, 1974a, 25). Clegg recalls an example of a lack of shared understanding of his philosophy about the effects of the quality of the physical environment and a lack of political good will towards this:

\footnotetext{
There was a time when my committee had just bought a gem of a building, Woolley Hall, near Wakefield. Its effect on people was created to a considerable extent by its magnificent mahogany interior doors which were cherished by those who used the building. A well-heeled councillor with a distinguished Cambridge degree did his best to persuade the governors to make money by removing the mahogany doors, selling them at a high price and replacing them with plywood. But in my experience those who seek quality and the effects which it can produce far outnumber those who care little for such matters. (Clegg 1980, 147).
}

In Clegg's evidence to the Central Advisory Council for Education (England) he estimated that well over 1,500 teachers participated in courses at Woolley Hall during 1963. In that year, about half the 10,000 teacher workforce of the West Riding attended some form of meeting, discussion group or in-service course in a school or other setting such as Woolley Hall.

Woolley Hall became a place 'where teachers not only exchanged past experiences but were strengthened by new ones’ (Times Educational Supplement, Sir Alec Clegg, 1974a, 25). Clegg was firm in this conviction that the right surroundings would add value in terms 
of the effects. Similarly he believed that as surroundings exert an important influence on behaviours, then the ability and potential of children to benefit from learning would be better served in a well-maintained and pleasant building (Times Educational Supplement, Sir Alec Clegg 1974c). Therefore he opposed cost-cutting measures which would have a detrimental effect on school buildings, a particular danger in smaller authorities at the time who were especially challenged by the need to make economies (Times Educational Supplement, Sir Alec Clegg 1974c). Clegg therefore needed to navigate and bridge differences and divisions in order to achieve and sustain this approach.

\section{'Sound and wise experiment': creating space and supporting teachers}

Clegg's work in building professional, political and community consensus created a space where the political divisions and complex terrain of the large and diverse West Riding area could be bridged. It enabled educational inequalities and lack of educational opportunities to be tackled and realised the potential for lives to be transformed. 'Evolution not revolution' was the watchword and his achievement was in building a consensus to enable agreed principles to be enacted but with scope to evolve according to local needs. An example of this was his proposal in a Policy and Finance Committee Memo in 1958 (Clegg 1958) for a gradual evolutionary approach to developing comprehensive education area by area to fit local circumstances and wishes, although this was not without its difficulties.

The inequalities and unfairness inherent in an elitist education system were concerns about which Clegg spoke compellingly and his fear that this was 'creating a recipe for social disorder’ (Annual Arthur Mellows Memorial Lecture, 1970).

Clegg recognised that not all practice in schools is good practice: 'unfortunately not all schools are good. There are many that follow the fashion of the day and succumb to the shallow thinkers who reduce practice to a series of clichés' (1972a, 6). However, if change 
was to be brought about, it would be through giving teachers freedom for 'sound and wise experiment' (Clegg, 1946a) and a fertile space for innovation and sharing experience.

He knew the transformative power of a good school on children's lives, how important it was to ensure that schools were good for all children in order avoid wastage of talent. This was crucial for schools in areas of the West Riding which were facing industrial decline, such as parts of South Yorkshire. The task of working with teachers to achieve this vision was accomplished through building a team of inspectors and advisory staff in whom he placed his trust and from whom he expected loyalty and commitment to the West Riding vision coupled with the professional and practical leadership to enthuse and motivate teachers, enhance their skills and make their practice truly transformative. He needed their views and judgements in such a large Authority area where, according to George (2000, 113), Clegg noted that 'it would take him approximately four years, visiting daily, to visit each school once, and therefore his reliance, but not dependence, on their judgement was considerable'.

This model of inspection and advice as a supportive service operating at a local level with a deep knowledge of the schools, their communities and the teachers who worked there stands in sharp contrast to the arrangements devised since the 1988 Education Reform Act (and subsequent legislation). Inspection has now become remote, judgemental, driven excessively by data and performance of pupils in tests and assessments and punitive in its effects. An adverse inspection result can damage a school and destroy careers of individual teachers. The prospect of inspection has lead to the development of defensive and managerial cultures in schools with micro management of teachers and devaluing of their professional judgement.

\section{Legacy and learning points}


The spirit of leadership embodied in the 'Nolan principles' of public life (for the seven principles see Maer 2015, 5) which post-date Clegg’s era, are in some ways anticipated in his leadership in the public interest including the interests of those whose needs are most neglected in the education system. He challenged this unfairness in the system and foresaw the potential social consequences when elitism dominates. It was of course a different policy context in the period of Clegg's tenure and the West Riding policy was to guide and influence decisions taken in the schools and trust and respect teachers to think for themselves, to 'make their own diagnoses and prescribe and administer their own treatments'. He reminded the Policy and Finance Sub-Committee of this in his Memo:

The Committee will of course be aware that it has always been the Authority's policy that matters of curricula and internal school organisation are the responsibility of the Headteacher and his staff. It is a policy that conforms with the national tradition of the English education system that differentiates it so sharply from most other educational systems. Because of it the Education Officer has always been most careful when issuing any directive, instruction or guidance to schools on behalf of the Committee, to avoid giving the impression that the Authority favours any particular teaching method, subject, school or class organisation. These matters are for the schools themselves to decide. (Memo Policy and Finance Sub-Committee Agendum 13, November 7, 1967).

The contrast with today is apparent where 'inside classrooms, teachers are caught between the imperatives of prescription and the disciplines of performance' (Ball 2013, 173). In the extract from the memo, local control at the school level and concern to safeguard school autonomy in decision-making on internal affairs is striking, especially in the current and very different policy context. Since Clegg's time, the education system has developed in accordance with an ideologically- informed line of reasoning which foregrounds 'freedom' from the local authority, devolved 'local control' at the school level and consumer 'choice'. This has played out in increasing inequality (Edwards and Tomlinson, 2002 cited in Olssen et al. 2004) and 
Because of its wide popular support, the ideology of choice presents a major challenge to educational administrators committed to equality of access and opportunity.

Education policies that promote choice at the cost of equity and social justice cannot be reversed until the political opportunities for such a change exist within the macrosocial context. Only by experiencing and monitoring the real social effects of these policies will people gradually work collectively to change them through the same democratic processes that have put them in place. (Olssen et al. 2004, 210)

The macrosocial context is now one where the powers and role in local planning have changed significantly. Prior to 1988 the local education authorities had responsibilities for oversight of matters such as staffing and resource management, the allocations of pupils to schools, the planning of provision in line with projections of the number of pupils and the places needed, and for in-service provision (Bell and Stevenson 2006, 100). Local authority responsibility for decision-making had been reduced by the 1980 Local Government Act and by subsequent legislation (Tomlinson 2005). The 'freedoms' and 'autonomy' for schools are mandated by a power structure which is centralised and heavily regulated and in which services to schools are now offered by a range of different providers who have entered this 'marketplace'.

What might be the relevance for our own times of Clegg's work as a great public servant during his tenure as CEO in the West Riding in a very different era? There are four possible areas we might seek to learn from.

Firstly, the need for CEOs (or their modern-day equivalents or successors) and those who seek to improve the lives of children, families and communities through the work of the public sector to consider their potential as political and community leaders. This is a controversial point, given the strong tradition of officer neutrality in local government. Leadbeater (n.d.) suggests a role for Directors of Children’s Services which moves between the worlds of professional organisations and the families and communities they serve, 
seeking to build communities that are resilient and adaptive with new combinations of services and voluntary endeavour. Clegg's legacy shows us that this is essentially a political role which requires clarity about the public value proposition, control of the authorising environment and leadership of the operating capacity, to use Moore’s typology (1995).

Secondly, Clegg's leadership style prefigures some of the recent discussion about the leadership of public services in time of volatility, uncertainty, complexity and ambiguity. The work of the Virtual Staff College (VSC) (Ghate, Lewis and Welbourn 2013) seeks to identify the characteristics required by public sector leaders to deal effectively with the current demands and challenges of rapid and unpredictable change. When viewed against the characteristics identified by the VSC research, Clegg's leadership style and approach has a strong resonance. He exhibited a strong personal commitment to social justice and articulated a clear set of personal and professional values which guided and directed the work of the service. His visible presence and regular visits to schools, engagement with teachers and reflection on these experiences to inform policy development demonstrate an ability to see the world from the 'dance floor' as well as the 'balcony' (Ghate, Lewis and Welbourn, 2013). The diverse views he heard were used to inform debate about practice and also political debate and decision making through the committee process. An important role of a system leader is to synthesise complexity and make sense of it for the wider organisation. Clegg did this through both formal channels of the West Riding committee structure and the informal notes, letters and conversations with his staff, politicians, teachers and other actors in the system. He understood the central importance of developing good relationships with people at all levels of a complex system and these relationships were characterised by integrity, honesty, empathy, reflection and self-awareness. Through these relationships he was able to lead by influence as much as positional authority. He understood that positional authority was 
not the only source of legitimacy and he sought to build alliances and partnerships based on local needs and circumstances.

Thirdly, Clegg requires us to re-evaluate what we mean by administration and bureaucracy. His work demonstrates a shift from a rigidly hierarchical and bureaucratic style of administration towards a more flexible and negotiative style in which schools and teachers were treated as partners in a shared endeavour. This is not without its irony since in today's government ideology the Department for Education would view Clegg as a manifestation of local authority control which imposes restrictions on teachers and exerts a malign influence on schools. In reality he created space within a formal bureaucratic structure that enabled teachers to develop their skill, professional practice, and philosophy and encouraged them to use their professional skill and judgement to transform children's lives. He managed the bureaucracy to create schools that were driven by teachers' professional practice and judgment. These professional skills were harnessed to produce schools that were responsive to children's and communities’ needs. Clegg's exercise of leadership fostered a mutually supportive, responsive and resilient system which allowed schools to flourish and respond to their communities within a framework of clear values. This provides a marked contrast with the micro-management of curriculum and assessment practiced by the current government under the guise of giving control back to schools.

Furthermore, Clegg recognised that an institution such as a school could not hope to thrive in isolation and needed to be part of a supportive partnership. Such a partnership was brokered and managed by the local authority and offered: professional support and solidarity; and engagement of and accountability to the community. Having eviscerated local authorities and their role in education, current government policy has removed these support and accountability mechanisms and indeed schools' connections with their local communities. 
The policy seeks to replace such supportive system-wide partnerships with market-based commercial transactions through the vehicle of multi-academy trusts without any necessary links or accountability to the communities served. Any notions of community accountability and local democratic influence are being removed in a programme of centralisation and commercialisation of education.

The fourth point is linked to this. Clegg was convinced that investment in teacher professional development and the freedom from bureaucracy, uniformity and prescription to allow them to develop their practice and scope to use their professional judgment, was a sound investment having huge potential to improve children’s lives. Practice should be illuminated by the 'vital and vigorous' unorthodox ideas of 'the experimenters, the researchers, the visionaries, and even from the eccentrics’ (Evidence from A.B. Clegg to the Central Advisory Council for Education (England) (n.d.) amongst the teaching force. A prerequisite for this must surely be the freedom and scope for individuality rather than compliance and unquestioning conformity. His preferred model for in-service teachers’ courses was a 'partnership' model of 'exploring with' rather than an 'authority' model of expert 'talking down to' others. The supportive and closely connected advisory service he developed ensured staff and organisational development was linked to both the authority vision and local needs and priorities. A dialogic collaborative partnership model was thus regarded as an effective one with follow-up and support in the school.

\section{Conclusion}

The local authority system is much diminished these days, following the gradual reduction of powers and funding as part of a drive by successive governments to dismantle the apparatus of local government. Indeed the statutory basis of the local education authority was removed in the 2004 Children Act. The West Riding authority served a large and diverse region and 
with Clegg as its Chief Education Officer there was a clear moral purpose to extend educational opportunities across the social spectrum. This was a guiding principle for education policy and planning in the West Riding and, because of Clegg's leadership and influence, more widely nationally and internationally. The commemorative blue plaque to Clegg in Wakefield where his office was located records his national influence on comprehensive education which was something to which he was committed. In 'About Our Schools' we learn that each of his three sons attended the first comprehensive school in the West Riding as it served the area in which they lived (Clegg 1980, ix). His exasperation with a preoccupation in education with measurement and testing would find kinship in much educational thought today. Believing that intelligence is not inherited or fixed but is instead shaped by social circumstances he opposed 11plus testing and selection. He knew that educational failure and lack of opportunity wastes talent and is a potential contributor to social unrest. A defining part of Clegg's life and vision was an attitude and approach motivated by a belief in the ways education can transform and enrich lives. He blended a deep humanity with shrewdness as a political operator. His practice embodied the characteristics needed to lead effectively in a complex system. His legacy as an outstanding public servant is widely acknowledged but he also should be remembered for articulating the values and laying the foundations of the kind of school system which would be best placed to respond to the economic, social and political complexity of today.

\section{Acknowledgements}

The assistance of the archivists for retrieval of items and making these available for the purposes of this research from the special collections at the University of Leeds Library, the National Arts Education Archive at the Yorkshire Sculpture Park; and the West Yorkshire Archive Service, Wakefield is gratefully acknowledged. The authors would like to express 
their gratitude to Sir Alec Clegg's sons for permission to quote from his papers in the special collections archive. We also wish to record our thanks to the two retired teachers for sharing their reflections and insights. The authors would like to thank Professor Jon Nixon for his valuable comments and suggestions on an earlier draft of the article. The authors would also like to thank the two anonymous referees who commented on the submitted original manuscript.

\section{Funding}

The authors would also like to acknowledge that the study was supported by York St John University and the Centre for Education and Policy Analysis (CEPA) at Liverpool Hope University, UK.

\section{References}

Ball, S. 2013. The Education Debate. 2nd ed. Bristol: The Policy Press.

Bell, L., and H. Stevenson. 2006. Education Policy. Process, Themes and Impact. Abingdon: Routledge.

Benn, M. 2012. School Wars: The Battle for Britain’s Education. London: Verso.

Boyle, E. 1971. "Edward Boyle in Conversation with Maurice Kogan" In The Politics of Education. Edward Boyle and Anthony Crosland in conversation with Maurice Kogan, edited by E. Boyle, A. Crosland, and M. Kogan. Harmondsworth: Penguin. 65-143.

Brighouse, T. 2008. “Sir Alec Clegg.” Education 3-13: International Journal of Primary, Elementary and Early Years Education 36 (2): 103-108. doi: 10.1080/03004270801994772. 
Carr, W. and A. Hartnett. 1996. Education and The Struggle for Democracy: The Politics of Educational Ideas. Buckingham: Open University Press.

Clegg, A. B. 1946a. Talk to Huddersfield Teachers, 3rd May (Ref AC/PL/23). The National Arts Education Archive (NAEA), Yorkshire Sculpture Park, West Bretton, Wakefield, Sir Alec Clegg Collection.

Clegg, A. B. 1946b. Talk to Headteachers of Grammar Schools, March 14th (Ref AC/PL/22). The National Arts Education Archive (NAEA), Yorkshire Sculpture Park, West Bretton, Wakefield, Sir Alec Clegg Collection.

Clegg, A. B. 1958. Policy \& Finance Committee 8/7/1958 Memo C50 from CEO on the development of the Service over the next 3 yrs. West Riding Education Authority Secondary Education 1954 - Dec 1959 Box 18. MS 731 'West Riding of Yorkshire Education Authority, Alexander Bradshaw Clegg directorship documents', The Brotherton Library, the University of Leeds Special Collection.

Clegg, A.B. 1966. The Education of the Professional Teacher. West Riding Education Authority 1902-74, A.B. Clegg’s Personal Files Box File 2. MS 731 ‘West Riding of Yorkshire Education Authority, Alexander Bradshaw Clegg directorship documents’ The Brotherton Library, the University of Leeds Special Collection.

Clegg, A. B. 1967. Policy and Finance Sub-Committee Agendum 13, 7th November, 1967 Memo 'Results of a Survey in West Riding Primary Schools: I.T.A., French and Streaming’. Box File 15 Primary Education 1944-74. MS 731 'West Riding of Yorkshire Education Authority, Alexander Bradshaw Clegg directorship documents' The Brotherton Library, the University of Leeds Special Collection. 
Clegg, A. B. 1970. Sir Alec Clegg Annual Arthur Mellows Memorial Lecture 1970, 'Education in Society’. West Riding Education Authority 1902-1974, A B Clegg’s Personal Files Box 2. MS 731 'West Riding of Yorkshire Education Authority, Alexander Bradshaw Clegg directorship documents’ The Brotherton Library, the University of Leeds Special Collection.

Clegg, A. B. November 1971. Speech 278A ‘An Informal, Extempore Address by Sir Alec Clegg to the Student Body, Toronto Teachers' College', West Yorkshire Archive Catalogue C1326, AC/PL/300. West Yorkshire Archive Service, Wakefield.

Clegg, A. B. 1972a. Convocation Lecture 'Attitudes, Opinions and Prejudices: their effect on the Education Service’. West Riding Education Authority, A B Clegg’s Personal Files Box 2. MS 731 'West Riding of Yorkshire Education Authority, Alexander Bradshaw Clegg directorship documents’ The Brotherton Library, the University of Leeds Special Collection.

Clegg, A. B. 21st April 1972b. Speech 'Them and Us', The Institute of Public Relations Conference, The Hague, Holland, Archive Catalogue C1326. West Yorkshire Archive Service, Wakefield.

Clegg, A. B. 3rd January 1972c. 'Disadvantage in Education', Presidential Address at North of England Education Conference. West Yorkshire Archive Service, Wakefield.

Clegg, A. B. 1973. Speech at the Barnsley and District Liaison Committee Conference, 25th November. West Yorkshire Archive WRD 11/10/4. West Yorkshire Archive Service, Wakefield.

Clegg, A. B. 1974a. “A subtler and more telling power.” Times Educational Supplement, September 27. 
Clegg, A. B. 1974b. “I wouldn’t pay him in washers.” Times Educational Supplement, October 4.

Clegg, A. B. 1974c. “Much to worry us.” Times Educational Supplement, October 11.

Clegg, A. B. May 1974d. Sir John Adams Lecture, Los Angeles, West Yorkshire Archive Catalogue C1326, AC/PL/351. Wakefield: West Yorkshire Archive Service.

Clegg, A. B. 1980. About Our Schools. Oxford: Basil Blackwell.

Clegg, A. B. n.d. 'What it means to me'. An article in a series in which 'some of the best known figures in Britain' wrote on a subject important to them. (Ref AC/PL/12/2). The National Arts Education Archive (NAEA), Yorkshire Sculpture Park, West Bretton, Wakefield, Sir Alec Clegg Collection.

Clegg, A.B. n.d. Document (Ref AC/PL/26). The National Arts Education Archive (NAEA), Yorkshire Sculpture Park, West Bretton, Wakefield, Sir Alec Clegg Collection.

Clegg, A. B. n.d. Evidence from A.B. Clegg, Education Officer, West Riding County Council to the Central Advisory Council for Education (England). Box File 15 Primary Education 1944-74. MS 731 'West Riding of Yorkshire Education Authority, Alexander Bradshaw Clegg directorship documents’ The Brotherton Library, the University of Leeds Special Collection.

Crawford, M. 2008. “Sir Alec Clegg.” Education 3-13: International Journal of Primary, Elementary and Early Years Education 32 (2): 101-102. doi: 10.1080/03004270801994764.

Department for Education 2016. Educational Excellence Everywhere, White Paper Cm 9230, London: DfE. 
Fielding, M. and P. Moss. 2011. Radical Education and the Common School: A Democratic Alternative. London: Routledge.

George, N. J. 2000. Sir Alec Clegg: Practical Idealist 1909-1986. Barnsley: Warncliffe Books.

Ghate, D., J. Lewis and D. Welbourn. 2013. Systems Leadership: Exceptional Leadership for Exceptional Times (Synthesis Paper). Nottingham: Virtual Staff College.

Gosden, P. H. and P. R. Sharp. 1978. The Development of an Education Service: The West Riding 1889-1974. Oxford: Martin Robertson.

Gronn, P. 2003. “Leadership: Who Needs It?” In School Leadership and Management 23 (3): 267-291.

Hobson, B. 2013. West Riding of Yorkshire. Cambridge: Cambridge University Press.

Hogan, J.M. 1986 Address at the funeral of Sir Alec Clegg, Saxton Church 25.01.1986 (Ref AC/PL/8). The National Arts Education Archive (NAEA), Yorkshire Sculpture Park, West Bretton, Wakefield, Sir Alec Clegg Collection.

Leadbeater, C. n.d. The role of the Director of Children’s Services: service provider, community leader - a think piece for the Director of Children’s Services Leadership Provision. Nottingham: the National College for Leadership of Schools and Children's Services.

Maer, L. 2015. “Committee on Standards in Public Life. Briefing Paper Number 04888, 27th May 2015.” Accessed $10^{\text {th }}$ September 2017. http://researchbriefings.parliament.uk/ResearchBriefing/Summary/SN04888 
Middlewood, D. Abbott, I. and Robinson, S. 2018. Collaborative School Leadership:

Managing a Group of Schools. London: Bloomsbury.

Moore, M. H. 1995. Creating Public Value: strategic management in government.

Cambridge, Massachusetts: Harvard University Press.

Newsam, P. 2008. "What price hyacinths? An appreciation of the work of Sir Alec Clegg.”

Education 3-13, 36 (2): 109-116. doi: 10.1080/03004270801994798

Olssen, M., J. Codd and A.M. O’Neill. 2004. Education Policy: Globalization, Citizenship and Democracy. London: Sage.

Su, F. and M. Wood. 2017a. "Towards an ‘ordinary’ cosmopolitanism in everyday academic practice in higher education." Journal of Educational Administration and History 49 (1): 2236. doi: 10.1080/00220620.2017.1252734

Su, F. and M. Wood (eds.) 2017b. Cosmopolitan Perspectives on Academic Leadership in Higher Education. Perspectives on Leadership in Higher Education. London and New York: Bloomsbury.

Tawney, R.H. 1964. Equality. London: Unwin Books.

Thomson, P., H.M. Gunter and J. Blackmore. 2014. "Series Forward" In Educational Leadership and Hannah Arendt, edited by H.M. Gunter. London: Routledge.

Taylor, C. 2009. A Good School for Every Child: How to Improve Our Schools. Abingdon: Routledge.

Times. 1986. “Sir Alec Clegg’ Obituary.” The Times, [London, England] January 21. The Times Digital Archive. Web. 4 March. 2017 
Tomlinson, S. 2005. Education in a Post-Welfare Society. 2nd ed. Maidenhead: Open University Press / McGraw-Hill Education.

Trimble, W.B.S. $18^{\text {th }}$ Nov 1971, Sir Alec Clegg Papers, Former West Riding Education Officer Records. Archive Catalogue C1326, AC/PL/300. West Yorkshire Archive Service, Wakefield. 